\title{
Fires: the main human impact on past environments in Patagonia?
}

\author{
Andrés Holz', C. Méndez², L. Borrero ${ }^{3}$, A. Prieto ${ }^{4}$, F. Torrejón ${ }^{5}$ and A. Maldonado ${ }^{6}$
}

\begin{abstract}
Multidisciplinary research in fire dynamics in the Patagonian-Andean region is incipient. In this review, we synthesize archaeological, anthropological, paleo-, dendro- and neoecological projects on past climate-human-fire-vegetation dynamics to establish ecological benchmarks to burning over time.
\end{abstract}

Fire, one of the most ubiquitous disturbances on earth, is a key driver of ecosystem dynamics globally. Fire controls major boundary dynamics and even the distribution of certain biomes. Hominins have altered the geography and regimes of fires from ca. 1.5 million years ago (Parker et al. 2016), and, in turn, fire became a key tool for evolutionary history, through impacts on landscape and resources, and constraints on knowledge, inter-group competition and geography. This work reviews the potential impact of human-set fires, favored by climate conditions, on forests and grasslands since their first appearance in two PatagonianAndean regions: the wetter western region, from the Pacific coast to the Andean peaks; and the drier eastern region, from the Andean peaks to the Atlantic coast (Fig. 1).

The role and sources of fire ignition in southern South America (SSA; south of ca. $38^{\circ} \mathrm{S}$ ) have been long-debated. Some have ignored topdown climate factors and highlighted largescale impacts of human-set fires (i.e. Heusser 1994), whereas others have preferred a perspective of fine-scale human impact favored by conducive climate-fire conditions (Markgraf and Anderson 1994; Holz and Veblen 2011a; Méndez et al. 2016). In Patagonia, fire was among the key tools of human groups for activities such as cooking, heating and hunting, as suggested by ethnographic sources. The archaeological records suggest that human occupation (and burning activity) was neither continuous nor homogenous over time and space (Fig. 1; 2e,f). The interpretation of the role of humans in setting fires in Patagonia is also a point of contention - some claim that first human appearances coincide with the onset of regional fire activity, others argue peaks in fire activity are only significant during periods when higher population densities were present throughout the landscape. For instance, at the northern margin of Patagonia, evidence of anthropogenic fire is documented from ca. 18.5-14.6 ka cal BP, the age of the earliest evidences of human settlement (i.e. Monte Verde at ca. $41^{\circ} \mathrm{S}$; Dillehay et al. 2015), and reached southernmost Patagonia (ca. 52$55^{\circ} \mathrm{S}$ ) at ca. $12.6 \mathrm{ka} \mathrm{cal} \mathrm{BP}$ (Fig. 1).

From a top-down perspective, fire activity in Patagonia has been controlled by natural ignition, biomass accumulation and climate variability at multiple time scales: from millennial (e.g. summer insolation and westerly winds strength and position; Whitlock et al. 2007), centennial (i.e. location of subtropical pacific anticyclone, and westerly winds strength and position; Holz et al. 2012), to decadal and interannual scales (e.g. El Niño Southern

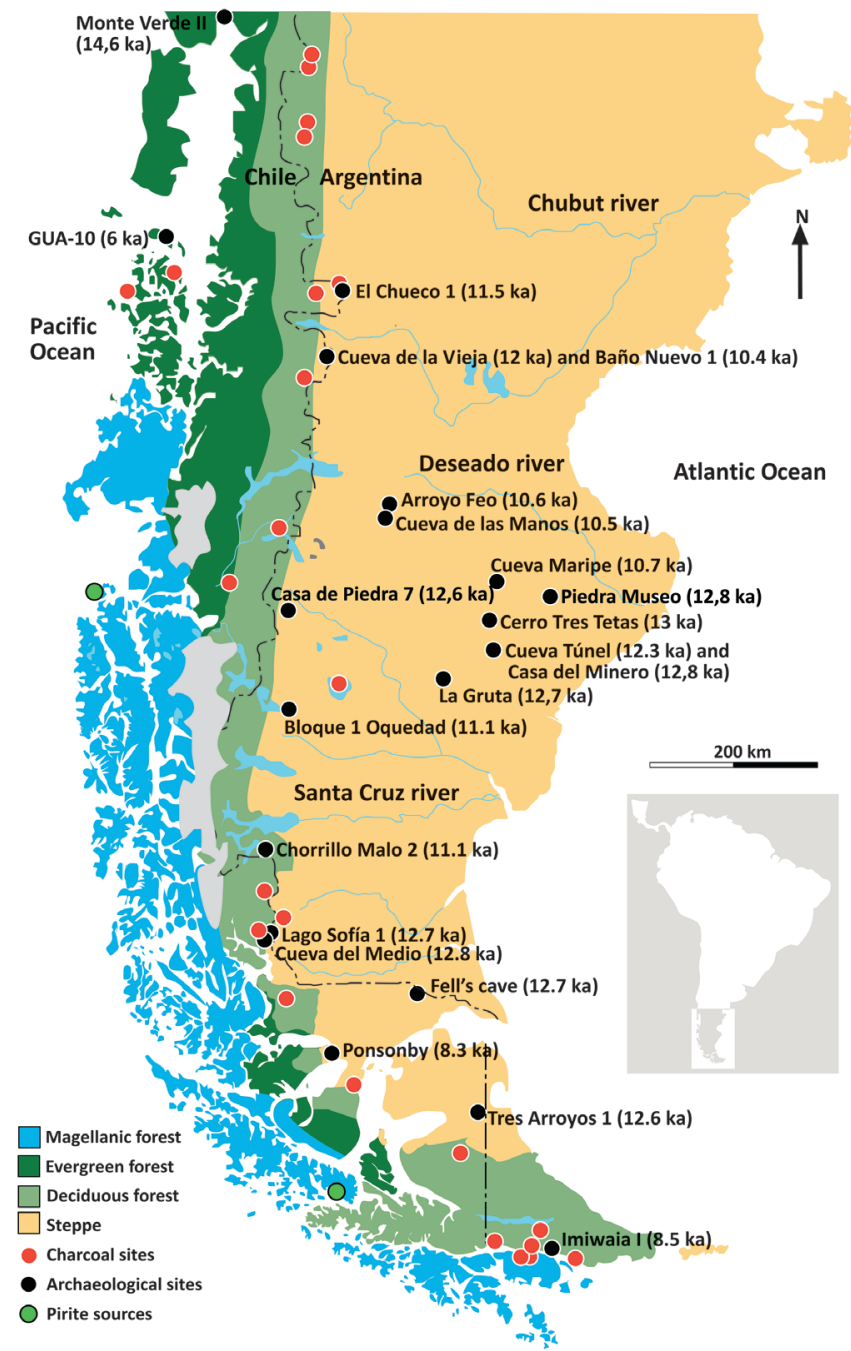

Figure 1: Location of regional earliest archaeological (calibrated ages BP in parenthesis) and paleoecological sites and main modern vegetation types cited in the text. The western and eastern Patagonian-Andean regions encompass the Magellanic and evergreen forests and deciduous forest and steppe, respectively.

Oscillation, ENSO; The Southern Annular Mode, SAM; Holz and Veblen 2011b). Under current climate conditions, fires occur during the Austral summer, and natural ignitions are relatively rare on the western Andean slope but common on the drier, eastern side of the Andes (Kitzberger et al. 2016).

\section{Climate, fire, vegetation, and human occupation}

In Patagonia, vegetation developed asynchronously across latitude and longitude, with broadly earliest establishment in Northern Patagonia, east of the Andes, and latest development in Southern Patagonia, west of the Andes. Wet/cool conditions were observed since the last glacial maximum and during the transition to the Holocene that favored establishment of initial forest taxa at ca. 16.5-13.5 ka BP in Northern Patagonia (ca. 37-44 S; Iglesias et al. 2016). In the early Holocene (ca. 11.5-8 ka BP), initial forest taxa established south of ca. $44^{\circ} \mathrm{S}$ (de Porras et al. 2012) under high El Niño (positive ENSO) activity, coinciding with drier conditions in Northern Patagonia, and wetter and warmer conditions in Central and Southern Patagonia, respectively (Fig. 2a-d). These conditions favored the highest peak in fire activity on record in Patagonia (Fig. 2e). During the Mid Holocene (ca. 8-4 ka BP), wet conditions in North and Central Patagonia coincided with a dry-to-humid transition in Southern Patagonia and low ENSO activity. Overall high climate variability was observed in the late Holocene (ca. $4 \mathrm{ka} \mathrm{BP}$ to present), with intermediate fire 
activity that co-occurred with mid-to-high ENSO activity, drying conditions in Northern and Central Patagonia, and very humid conditions in Southern Patagonia - presumably due to a southward shift of the westerlies (rather than changes in human ignition or westerlies strength; Fig. 2a-e). Over the last several hundred years, fires occurred mainly during fire-prone phases of ENSO and SAM (Holz and Veblen 2011a).

In western Patagonia, fire records date back to ca. 11 ka BP (e.g. Holz et al. 2012), which precede human arrival (ca. Mid Holocene, Fig. 2f). In this region, the archaeological record is richest over the last two millennia (Reyes et al. 2015). At the time of first European contact (ca. late 1500s), indigenous groups practiced localized slash and burn agriculture (ca. $40-44^{\circ} \mathrm{S}$ ). Further south in the channels, with cooler and wetter conditions, small canoeist groups lived off seal hunting, fishing and used pyrite for starting bonfires (Fig. 1). These groups were known to transport active bonfires in their canoes. Pyrite was also commonly used to burn small coastal temperate rainforest patches that were subsequently harvested for fuel. Starting in the mid-1750s, European-settlers burned vast extensions of native forests to facilitate access to coastal rainforest trees of valuable timber (Holz and Veblen 2011a). On the western Andean slopes, most tree species can neither resist nor recover following large, high severity events, which eliminate seed source. Some tree species, however (e.g. Pilgerodendron) can recover from sporadic, low-to-moderate fire severity events (Kitzberger et al. 2016).

\section{Along the eastern Andean foothills, fires} have been recorded as far back as ca. $17 \mathrm{ka}$ BP (Iglesias et al. 2016), and precede human contact (Fig. 1, 2e,f). Tehuelche people set fires for smoke signaling and hunting - activities that vastly increased in the 18th century with the introduction of horses. Tehuelche people had higher demographic concentrations than coastal groups and were known for their series of bonfires burning in front of and inside their toldos (hide huts). Some of the dominant forest taxa in this region possess traits that allow them to resist fire (e.g. thick bark and self-pruned stem in Araucaria) and quickly re-establish following fires (e.g. sprouting capabilities in Nothofagus antarctica; Kitzberger et al. 2016).

\section{Regional trends and multidisciplinary research in Patagonia}

At the largest scale, fire in Patagonia appears to have been shaped by both climate conditions and human ignitions. Overall trends in fire activity correspond well with millennial-scale variability in moisture availability (Fig. 2). The highest fire peak on record, however, took place not long after first human contact across Patagonia, and hence cannot be explained by climate conditions alone. These big-picture results suggest that climate conditions control fire activity at large scales, but human ignitions were responsible for pulses in fires (as long as climate conditions were suitable for burning).

At this large scale, it is difficult to assess the relationship between demographic density

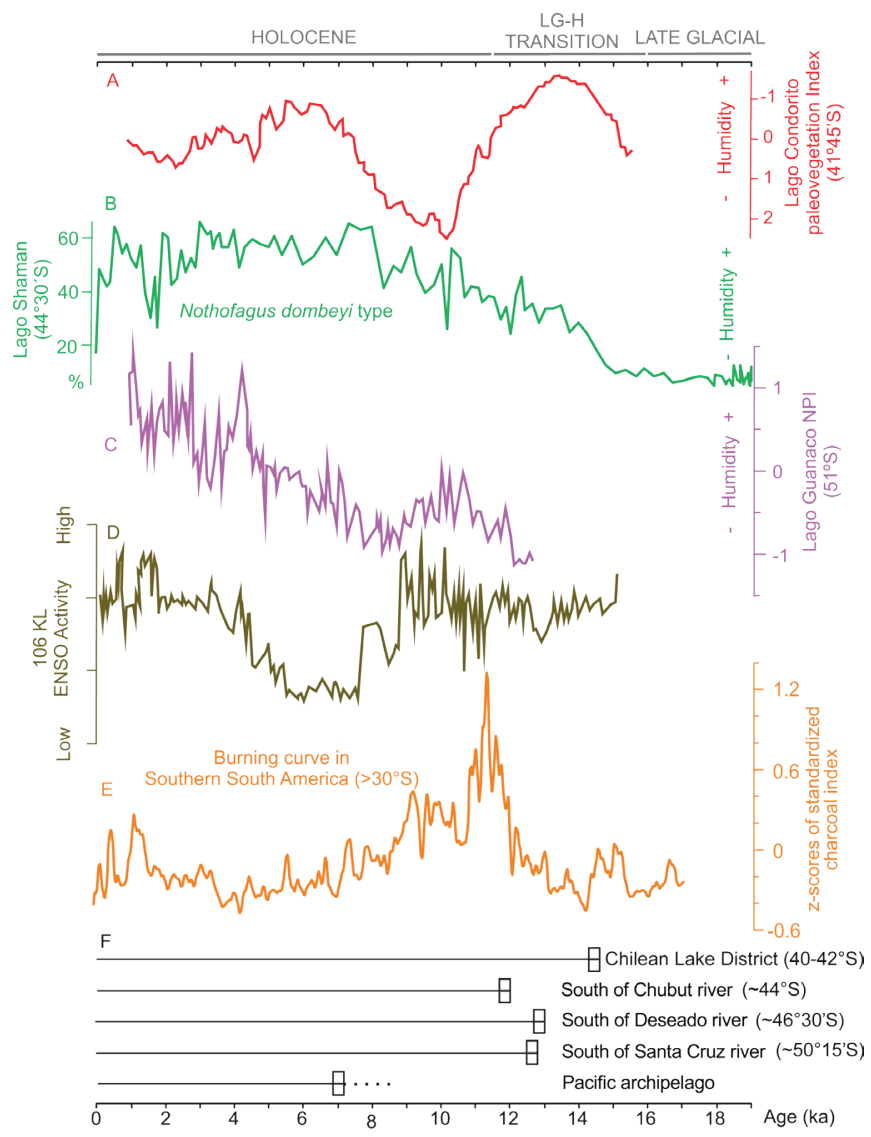

Figure 2: Changes in climate, fire and human occupation in southern South America over time. Pollen-based humidity paleo-indices for Northern (A), Central (B), and Southern (C) Patagonia. (D) Lithic flux rate (\% of maximum; Marine core ENSO reconstruction at $12^{\circ} \mathrm{S}$ ). (E) Burning curve in SSA ( $>30^{\circ} \mathrm{S}$, smoothed with a 200 -year window. (F) First-arrival dates based on earliest regional archaeological records.

and the impact of human-set fires. Instead, site-specific studies with multidisciplinary approaches seem more useful; e.g. archaeo-paleoecological paired work in the deciduous forest and steppe ecotone in Central Patagonia $\left(44^{\circ} \mathrm{S}\right)$ found that human presence strongly correlate with fires throughout the Holocene, especially during periods of high fuel availability (i.e. wet periods; Fig. 1; Méndez et al. 2016). In the evergreen forest and peatland ecotone of western Patagonia $\left(47^{\circ} \mathrm{S}\right)$, paired paleo-dendro-neoecological data with historical analyses indicate that indigenous fine-scale burning was common before European-settlers' arrival (Fig. 1; Holz and Veblen 2011a). Studies also indicate that 20th-century burning reached peaks up to four times higher than at any time during the Holocene (Holz et al. 2012) and has transformed the plant community into an alternative, more flammable vegetation state (Kitzberger et al. 2016). Studies conducted in similar biophysical settings in New Zealand suggest that relatively small groups of Maori people were able to burn and transform very large extensions of temperate forests ca. 0.8 ka BP because of vegetation flammability-fire feedbacks (Perry et al. 2012). We expect that ongoing multidisciplinary work will shed new light on the role that humans had on shaping past environments in Patagonia.

\section{ACKNOWLEDGEMENTS}

This research was supported by the US NSF (0966472), FONDECYT $(1130128,1130151,1120765)$ and FONDAP CRHIAM (15130015).
${ }^{2}$ Department of Anthropology, University of Chile, Santiago, Chile

${ }^{3}$ Instituto Multidisciplinario de Historia y Ciencias Humanas, Buenos Aires, Argentin

${ }^{4}$ Campus Natales, University of Magallanes, Punta Arenas, Chile

${ }^{5}$ Aquatic Systems Research Unit, University of Concepción, Chile

${ }^{6}$ Centro de Estudios Avanzados en Zonas Áridas, University of La Serena, Chile

\section{CONTACT}

Andrés Holz: andres.holz@pdx.edu

\section{REFERENCES}

de Porras ME et al. (2012) Quat Sci Rev 50: 71-85

Diaz MF et al. (2007) Forest Ecol Manag 244: 32-40

Dillehay TD et al. (2015) PLoS ONE 10, doi: 10.1371/journal.pone. 0141923

Heusser CJ (1994) Rev Chil Hist Nat 67: 435-443

Holz A et al. (2012) Clim Past 8: 451-466

Holz A, Veblen TT (2011a) Palaeogeogr Palaeoclimatol Palaeoecol 311: 82-92

Holz A, Veblen TT (2011b) Geophys Res Lett 38, doi:10.1029/2011GL047674

Iglesias V et al. (2016) Palaeogeogr Palaeoclimatol Palaeoecol 457: 195-208

Kitzberger T et al. (2016) New Zeal J Bot 54: 247-272 Markgraf V, Anderson L (1994) Rev IG Sao Paulo 15: 33-47

Méndez C et al. (2016) Front Ecol Evol 4: doi: 10.3389/ fevo.2016.00100

Parker CH et al. (2016) Evol Anthropol 25: 54-63 Perry GLW et al. (2012) Glob Change Biol 18: 1609-1621 Reyes O et al. (2015) J I Coast Archaeol 10: 207-231

Whitlock C et al. (2007) Quat Res 68: 28-36 